\title{
Tepung ubi kayu (manihot esculenta) dan tepung tempe kedelai mempengaruhi pengembangan volume dan mutu gizi protein roti tawar
}

\author{
Nanik Hamidah ${ }^{1}$,Anang M Legowo ${ }^{2}$, dan Syaiful Anwar ${ }^{2}$
}

\begin{abstract}
Backround: Bread was a carbohydrate source's food, was made from wheat flour. Cassava flour as substitution for wheat flour by modification process used physic method (boiling) to obtain resitant starch. Collaboration cassava flourwith tempeh flour to add protein velue. The research for attest substitution wheat flour with cassava flour and tempeh flour influence to volume characteristics and quality of protein nutrient for white bread

Methods:The research methods used exsperiment with completely randomized design which consists of 5 treatment with 4 replications. Cassava flour was processed by modification used physical methods (boiling).Proportion for tempeh and cassava flour 0\%, 6\%, 12\%, 18\%, 24\% combinated by tempeh flour proportion 3:1. Dependent variabel were size of volume white bread, quality of protein nutrient. Data Analysis used Anova.

Result:The result of those research were found that the best chararacteristic from white bread was treatment 6\%. Size of volume $3,15 \mathrm{ml} / \mathrm{g}$ was size volume bread from composite flour ingredient. Quality of nutrient for protein consist of protein content increased from $6,15 \%$ to $8,76 \%$, protein digestibility increased from 11,7\% to 13,83\% was compared for treatment $0 \%$.

Conclusion: Substitution wheat flour with cassava flour and tempeh flour influence white bread organoteptic (texture, colour (crumb, crust), taste), size of quality of nutrient protein.
\end{abstract}

Keywords: Cassava Flour; Tempeh Flour; Volume Bread; Quality of protein nutrient.

\begin{abstract}
ABSTRAK
Latar Belakang:Roti merupakan makanan sumber karbohidrat, terbuat dari tepung terigu. Tepung ubi kayu sebagai substitusi tepung terigu melalui proses modifikasi menggunakan metode fisik (perebusan) untuk mendapatkan pati resisten. Penambahan tepung ubi kayu dengan tepung tempe kedelai untuk menambah nilai gizi protein. Tujuan penelitian membuktikan substitusi tepung terigu dengan tepung ubi kayu dan tepung tempe kedelai dapat mempengaruhi ukuran volume dan mutu gizi protein roti tawar.

Metode: Penelitian ini merupakan true exsperimentalmenggunakan Rancangan Acak Lengkap (RAL) 5 perlakuan dan 4 kali ulangan. Tepung ubi kayu diproses melalui modifikasi menggunakan metode fisik (perebusan). Proporsi substitusi tepung terigu dengan ubi kayu 0\%, 6\%, 12\%, 18\%, 24\% dikombinasi dengan tepung tempe kedelai perbandingan 3:1. Variabel yang diukur adalah volume roti dan mutu gizi protein roti tawar. Analisi data menggunakan Anova.

Hasil:Hasil penelitian karakteristik roti tawar terbaik adalah perlakuan 6\%. Volume roti 3,15ml/g dalam kategori volume normal roti berasal dari tepung komposit. Mutu gizi protein terdiri dari kadar protein meningkatdari 6,15\% menjadi 8,76\%, daya cerna protein meningkatdari 11,7\% menjadi 13,83\%dibandingkan dengan standar perlakuan $0 \%$.

Simpulan: Substitusi tepung terigu dengan tepung ubi kayu dan tepung tempe kedelai mempengaruhi volume roti, mutu gizi protein roti tawar.
\end{abstract}

Kata Kunci: Tepung Ubi Kayu; Tepung Tempe Kedelai; Volume roti; Mutu Gizi Protein

\section{PENDAHULUAN}

Roti makanan sumber karbohidrat yang lazim dan banyak dikonsumsi masyarakat, terbuat dari tepung terigu, air, dan ragi yang pembuatannya melalui tahap pengulenan, fermentasi (pengembangan), dan pemanggangan dalam oven. Tepung terigu merupakan bahan pangan yang memiliki indeks glikemik(IG) rendah, berasal dari gandum sedang dibudidayakan di Indonesia. ${ }^{1}$

Ubi kayu merupakan tanaman komoditas pangan, dapat dibudidayakan di Indonesia, sebagai sumber karbohidrat untuk membuat roti tawar. Pengolahan ubi kayu menjadi tepung melalui modifikasi menggunakan

\footnotetext{
1. STIKes Widya Cipta Husada (WCH) Malang

2. Fakultas Pertanian dan Peternakan, Universitas Diponegoro.
}

metode fisik (perebusan) untuk mendapatkan pati resisten. Pati resisten adalah pati yang tidak dapat dicerna di dalam usus halus tetapi dapat terfermentasi di dalam usus besar. Pati yang memiliki presentase amilosa tinggi mudah mengalami retrogradasi akibat pemanasan dalam air mendidih untuk membentuk pati resisten, sebaliknya presentase amilopektin yang rendah akan mempengaruhi kualitas pengembangan jika digunakan sebagai bahan pembuatan roti. ${ }^{2-4}$

Tempe kedelai merupakan makanan tradisional, diminati oleh masyarakat, selain harganya murah, juga memiliki kandungan isoflavon tinggi, serat tinggi, IG rendah $($ glycemic index $<55)$ dan protein nabati yang tinggi. Pengolahan tempe kedelai menjadi tepung yang dikombinasi dengan tepung ubi kayu untuk menambah nilai gizi protein roti tawar. ${ }^{7-10}$ 
Pengembangan roti tawar sebagai aktivitas ragi Saccharomyces cerevisiae yang membebaskan gas $\mathrm{CO}_{2}$ selama proses fermentasi, yang ditahan di dalam adonan oleh gluten. Berdasarkan latar belakang diatas maka dalam penelitian ini, penulis akan melakuan penelitian tentang pengaruh penambahan tepung ubi kayu (Manihot esculenta) yang dimodifikasi menggunakan metode fisik (perebusan) dan tepung tempe kedelai sebagai substitusi tepung terigu terhadap volume roti tawar sertamutu gizi protein. ${ }^{3}$

\section{BAHAN DAN METODE}

Penelitian dilakukan di Laboratorium Teknologi Pangan dan Kimia Pangan Universitas Muhammadiyah Semarang.

\section{Bahan dan Alat}

Bahan roti tawar menggunakan bahan utama tepung terigu berprotein tinggi dan bahan pendukung meliputi susu, ragi, telur, garam, bread improver, shortening, air, kemudian sebagai bahan subtitusi digunakan tepung ubi kayu dan tepung tempe kedelai.
Bahan kimia yang digunakan untuk analisis meliputi: air suling, Na-tetra borat, $\mathrm{K}_{2} \mathrm{SO}_{4}, \mathrm{HgO}, \mathrm{H}_{2} \mathrm{SO}_{4}, \mathrm{NaOH}-$ $\mathrm{Na}$ Thio, enzim pepsin, buffer whalphole.

Alat yang digunakan saringan, timbangan ketelitian 1g, mixer, loyang, spatula, pisau, kuas, oven, cabinet drying. labu kjeldahl, pipet volume, cawan porselen, tabung reaksi, sentrifus, spektrofotometer, kertas saring Whatman 41, timbangan analitik.

\section{Metode Penelitian}

Metode penelitian ini menggunakan Rancangan Acak Lengkap (RAL), dilakukan dengan proporsi berbeda sebanyak 5 perlakuan dengan pengulangan sebanyak 4 kali.

\section{Pelaksanaan Penelitian}

Penelitian diawali dengan pembuatan tepung dari ubi kayu kualitas Malang 4 yang diperoleh dari BALITKABI, pembuatan tepung dari tempe kedelai merek "Kedelai Murni Ps. Kr. Ayu", pembuatan roti tawar substitusi tepung terigu dengan tepung ubi kayu dan tepung tempe kedelai, kemudian dianalisis volume roti, mutu gizi protein roti tawar.

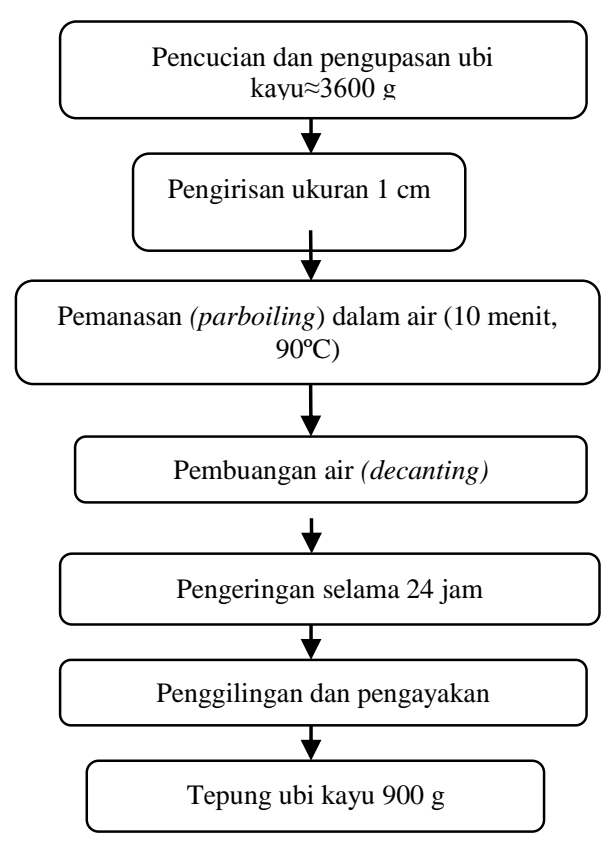

Gambar 1. Cara Pembuatan Tepung Ubi Kayu Dengan Modifikasi Fisik (Pre-Gelatinisasi)

1. Pembuatan Tepung Ubi Kayu

Tepung ubi kayu dibuat dengan tahapan pengupasan, pencucian, pengirisan, perebusan $90^{\circ} \mathrm{C}$ 10 menit, penirisan, pengeringan $50^{\circ} \mathrm{C} 24 \mathrm{jam}$, penggilingan, pengayakan 80 mesh, dan penimbangan (Gambar 1).

2. Tepung Tempe Kedelai

Tepung tempe kedelai dibuat dengan tahapan pemotongan, pengukusan (blancing) $105^{\circ} \mathrm{C} 9$ menit, pengirisan, pengeringan $50^{\circ} \mathrm{C} 24 \mathrm{jam}$, penggilingan, pengayakan 80 mesh (Gambar 2).

3. Pembuatan Roti

Roti tawar dibuat dengan substitusi tepung ubi kayu dan tempe kedelai dengan perbandingan 3:1 pada substitusi $0 \%, 6 \%, 12 \%, 18 \%$ dan $24 \%$. Proses pembuatan roti tawar ubi kayu secara garis besar meliputi proses pencampura, pengadonan, fermentasai, pencetakan dan pemanggangan (Gambar 3). 


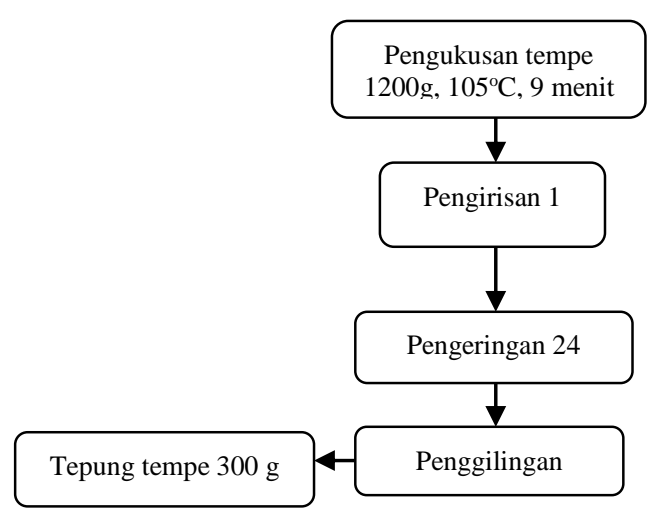

Gambar 2. Cara Pembuatan Tepung Tempe Kedelai

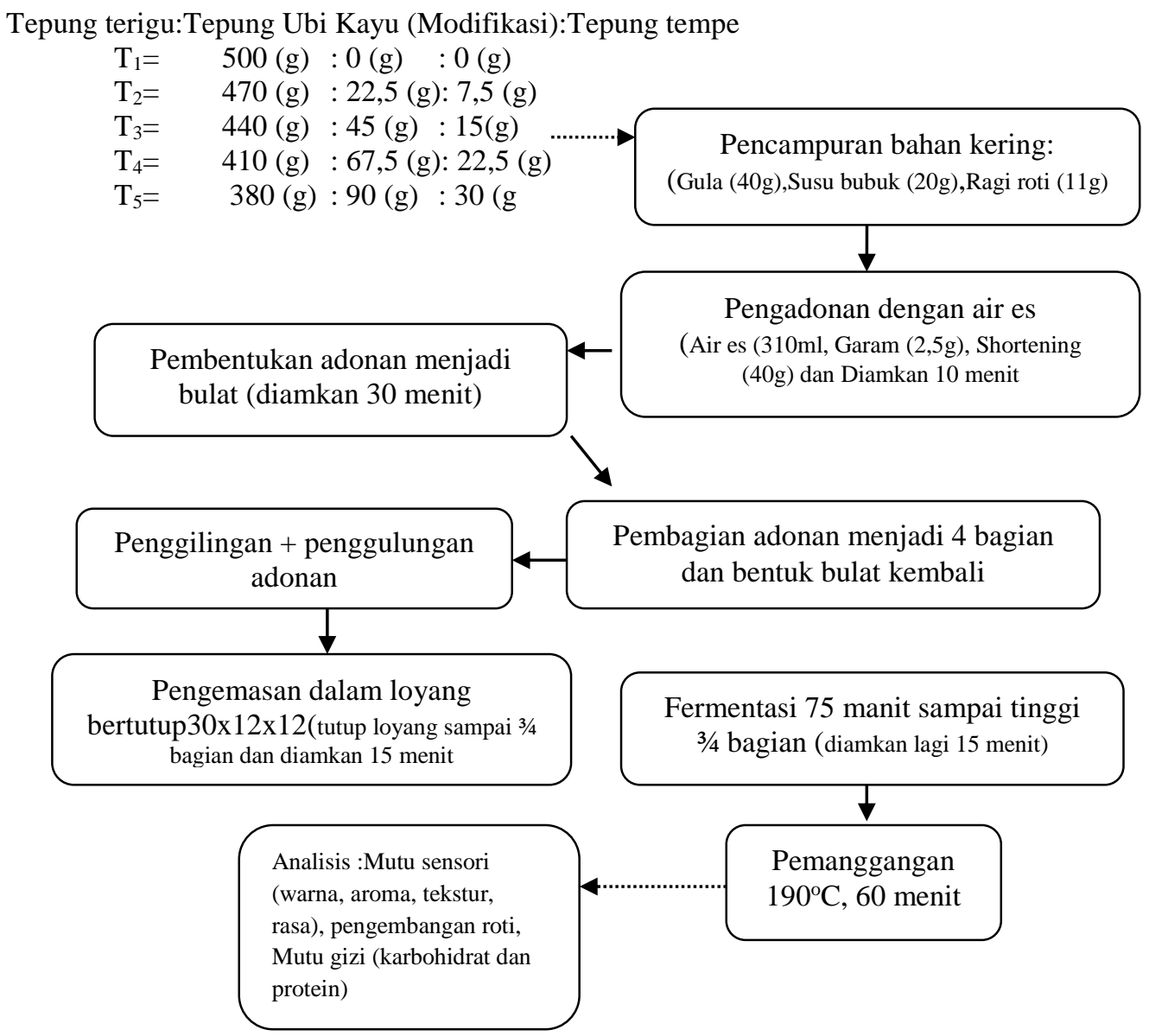

Gambar 3. Prosedur Pembuatan Roti Tawar Substitusi Tepung Ubi Kayu Modifikasi Fisik (Pre-Gelatinisasi) dan Tepung Tempe

4. Pengukuran Volume Roti

Volume roti diukur menggunakan perpindahan rapeseed, kemudian dianalisis menggunakan metode AACC (American Association of Cereal Chemist) (Gambar 4).

Volume roti tertentu ditentukan dengan membagi volume roti dengan berat roti yang sesuai $\left(\mathrm{cm}^{3} / \mathrm{g}\right) .{ }^{15}$
Biji-bijian yang berpindah tempat oleh roti $(\mathrm{L})=$ $\mathrm{Cg}+$ berat biji tumpah $-3500 \mathrm{~g}$.

Volume roti $(\mathrm{V})=\frac{\mathrm{L} \times 5660.37 \mathrm{~cm}^{3}}{=}$

C 


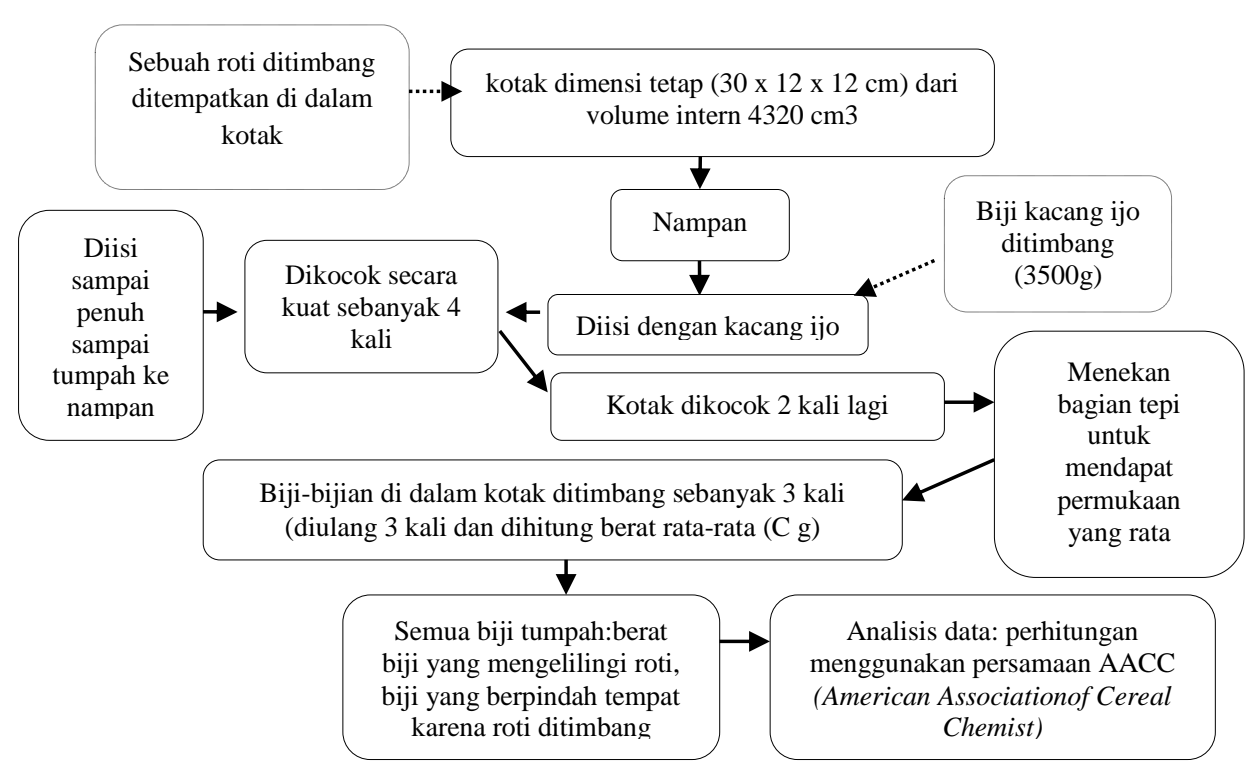

Gambar 4. Prosedur Mengukur Pengembangan Roti Tawar

5. Pengukuran Mutu Gizi Protein

Mutu gizi protein roti tawar meliputi kadar protein dan daya cerna protein. Kadar protein ditentukan menggunakan metode mikro kjeldahl. Daya cerna protein diuji secara in vitro (Gambar 5), merupakan presentase kadar nitrogen $(\mathrm{N})$ filtrat yang menunkukkan kadar protein tercerna dengan kadar nitrogen $(\mathrm{N})$ total bahan menunjukkan protein awal total. Nilai daya cerna protein dihitung dengan menggunakan rumus sebagai berikut:

(mg N dalam filtrat $\times 6,25 \times 100 \%)$

$\%$ protein tercerna $=$

(mg bahan $\mathrm{x} \%$ protein bahan)
6. Analisis Data

Analisis menggunakan Anova. Selanjutnya dilakukan uji lanjutan menggunakan uji beda Tukey.

\section{HASIL}

\section{Analisis Volume Roti}

Hasil nilai rerata pengukuran volume roti tawar dari kelima perlakuan disajikan pada Gambar 6. Ada perbedaan ukuran volume roti tawar yang signifikan pada kelima perlakuan roti tawar $(\mathrm{p}=0,001)$. Rerata ukuran volume pada perlakuan $0 \%, 6 \%$, dan $12 \%$ tidak berbeda nyata masing-masing $3,77 \mathrm{ml} / \mathrm{g}$, $3,15 \mathrm{ml} / \mathrm{g}, 2,88 \mathrm{ml} / \mathrm{g}$ ditandai dengan huruf a, ab, dan abc.

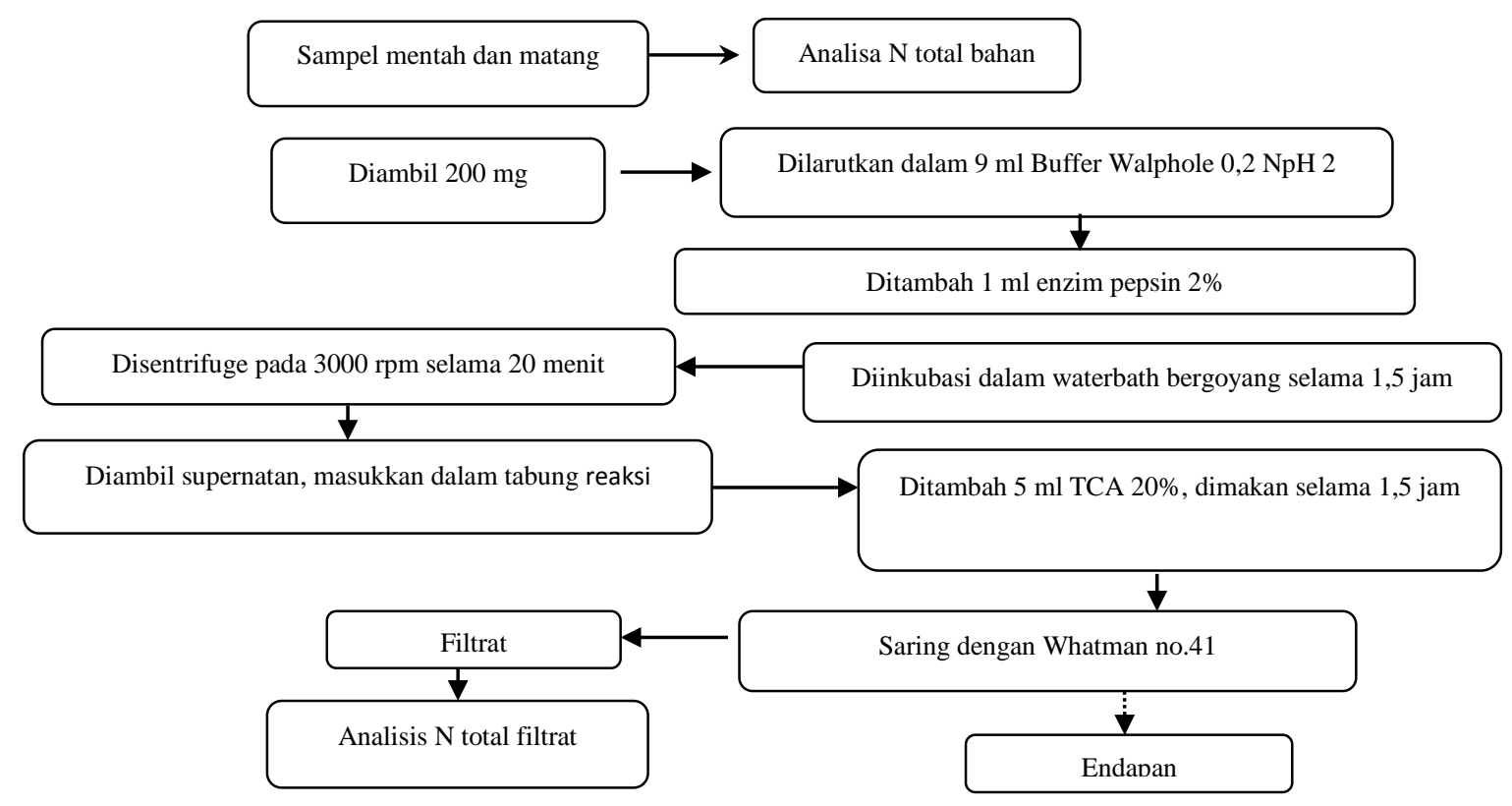

Gambar 5 Diagram Alir Analisis Kecernaan Protein Secara In- Vitro 


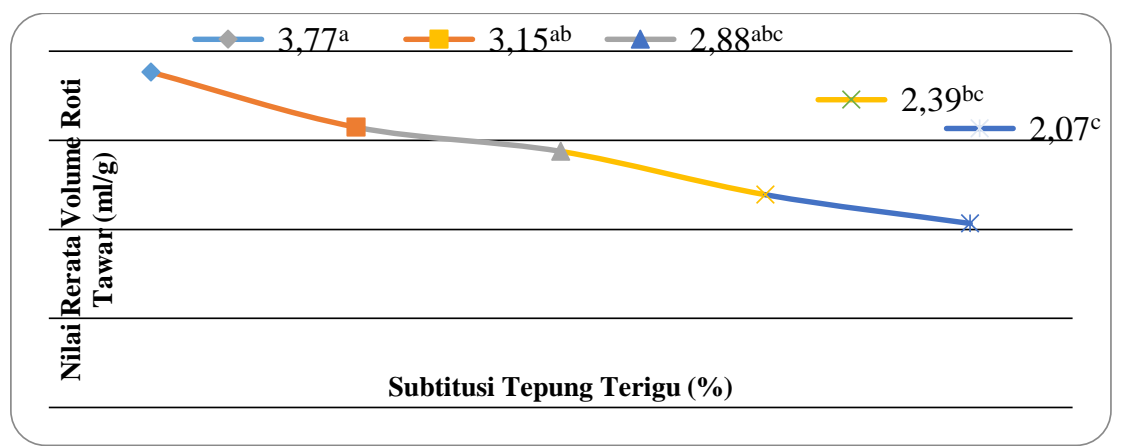

Gambar 6. Grafik Rerata Volume Roti Tawar berdasarkan Perlakuan

\section{Analisis Mutu Gizi Protein}

Hasil nilai rerata kadar protein roti tawar dari kelima perlakuan disajikan pada Gambar 7. Ada perbedaan kadar protein yang signifikan pada kelima perlakuan roti tawar $(\mathrm{p}=0,0001)$. Rerata kadar protein berbeda nyata pada kelima perlakuan $0 \%, 6 \%, 12 \%$, $18 \%$, dan $24 \%$ masing-masing sebesar $6,15 \%, 8,76 \%$, $11,69 \%, 14,57 \%$, dan $16,57 \%$ yang ditandai dengan huruf e, d, c, b, a.

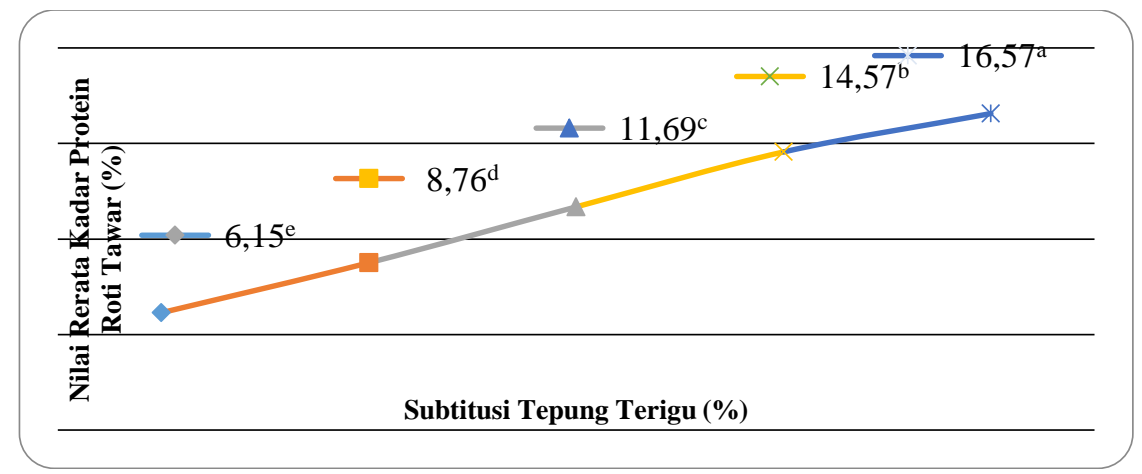

Gambar 7. Grafik Rerata Kadar Protein Roti Tawar berdasarkan Perlakuan

Hasil rerata nilai daya cerna protein juga semakin meningkat dengan penambahan tepung ubi kayu yang dikombinasi dengan tepung tempe kedelai (Gambar 8). Ada perbedaan nilai daya cerna protein yang signifikan pada kelima perlakuan roti tawar $(p=0,0001)$. Nilai rerata daya cerna protein roti tawar pada perlakuan $0 \%, 6 \%, 12 \%, 18 \%$ dan $24 \%$ saling berbeda nyata masing-masing sebesar $11,57 \%$, $13,83 \%, 15,97 \%, 18,39 \%, 21,14 \%$ ditandai dengan huruf e, d, c, b, a.
Peningkatan nilai rerata daya cerna protein roti tawar disebabkan penambahan tepung tempe kedelai. Tepung tempe kedelai dibuat dari tempe kedelai dari bahan kedelai murni. Tempe kedelai sebagai bahan pangan sumber protein mudah dicerna (92$100 \%) .{ }^{33}$ Pengolahan kedelai menjadi tempe melalui fermentasi oleh kapang dapat menghidrolisis senyawasenyawa kompleks menjadi senyawa sederhana yang mudah dicerna oleh manusia. ${ }^{31}$

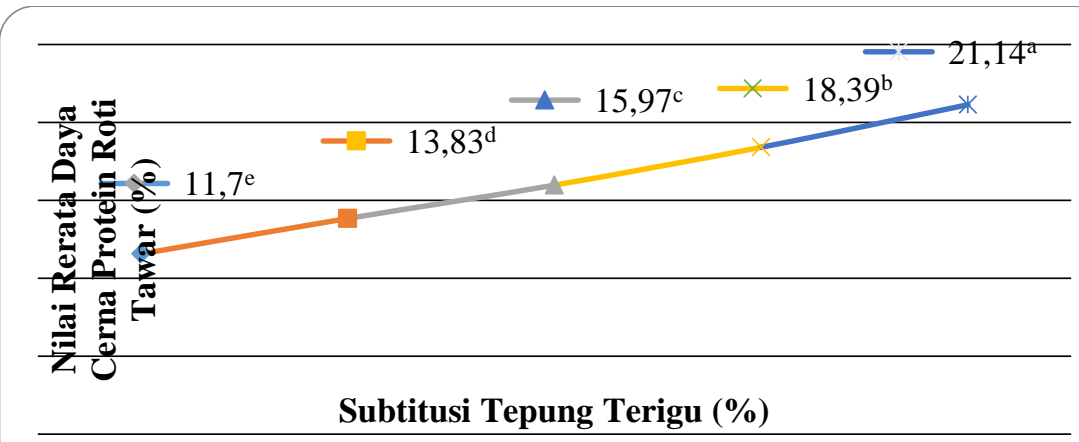

Gambar 8. Grafik Rerata Daya Cerna Protein Roti Tawar berdasarkan Perlakuan 


\section{Hubungan Kadar Protein dan Nilai Daya Cerna Protein Roti Tawar}

Pola perubahan antara kadar protein dan nilai daya cerna protein menunjukkan bahwa semakin meningkat kadar protein roti tawar semakin meningkat daya cerna proteinnya (Gambar 9).

Peningkatan kadar protein dimulai dari $6,15 \%$ pada perlakuan $0 \%$ menjadi $8,76 \%$ pada perlakuan $6 \%$, dan terus meningkat pada perlakuan $12 \%, 18 \%$ dan $24 \%$ masing-masing $11,68 \%, 14,57 \%$, dan $16,57 \%$ sedangkan daya cerna protein dimulai dari 11,57 pada perlakuan $0 \%$ menjadi $13,83 \%$ pada perlakuan $6 \%$, dan terus meningkat pada perlakuan $12 \%, 18 \%$ dan $24 \%$ masing-masing $15,97 \%, 18,39 \%$, dan $21,14 \% . \%$. Selisih kenaikan antara kadar protein digambarkan dalam persamaan garis regresi $y=6,213+0,444 x$ dan daya cerna protein digambarkan dalam persamaan garis regresi $\mathrm{y}=11,440+0,395 \mathrm{x}$ untuk setiap peningkatan substitusi tepung terigu $6 \%$ masing-masing $0,444 \%$ dan $0,395 \%$.

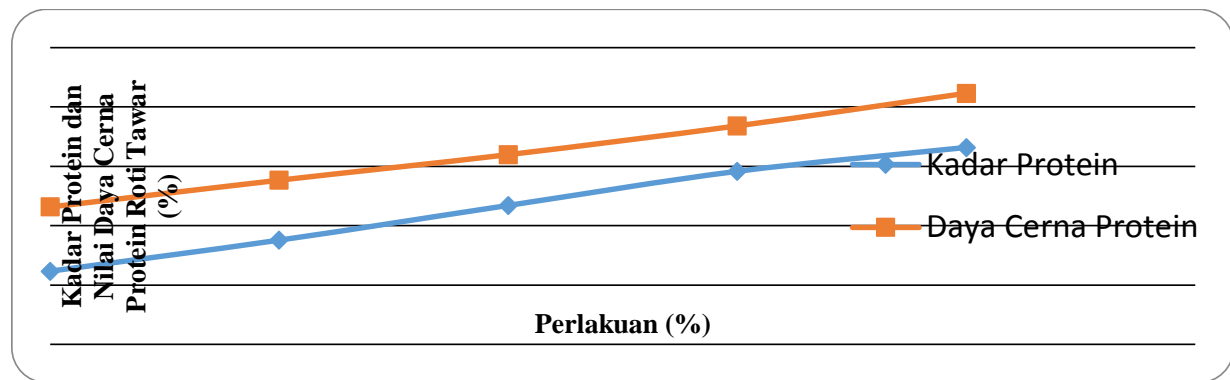

Gambar 9. Hubungan Kadar Protein dan Nilai Daya Cerna Protein Roti Tawar

\section{PEMBAHASAN}

Pada penelitian ini menemukan terdapat perbedaan ukuran volume roti tawar yang signifikan pada kelima perlakuan roti tawar. Menurut teori ukuran volume roti yang dibuat dari tepung komposit akan turun $3 \mathrm{ml} / \mathrm{g}$. Perlakuan $6 \%$ sebagai gambaran penurunan ukuran volume roti tawar yang mendekati perlakuan 0\%.Tepung terigu mengandung protein giliadin dan glutenin yang akan membentuk gluten. Gluten mempunyai fungsi dalam menahan gas $\mathrm{CO}_{2}$ yang dihasilkan dalam proses fermentasi ragi Saccharomyces cerevisiae sehingga berperan penting dalam pengembangan volume roti. ${ }^{1917,35,37}$

Kadar protein berbeda signifikan pada kelima perlakuan roti tawar. Kadar protein roti tawar dengan semakin bertambahnya jumlah tepung yang disubstitusi semakin meningkat kadarnya. Peningkatan kadar protein disebabkan adanya penambahan tepung tempe kedelai sebagai kombinasi dari tepung ubi kayu. Tempe kedelai mengandung protein 20 gram per 100 gram bahan dibandingkan dengan protein dalam tepung terigu sekitar $12 \%{ }^{8-10}$

Analisis daya cerna protein diuji dengan cara in vitro menggunakan enzim pepsin untuk memberikan gambaran berlangsungnya proses pencernaan protein di lambung dan usus. ${ }^{43}$ Hasil rerata nilai daya cerna protein juga semakin meningkat dengan penambahan tepung ubi kayu yang dikombinasi dengan tepung tempe kedelai. Ada perbedaan nilai daya cerna protein yang signifikan pada kelima perlakuan roti tawar. Peningkatan nilai rerata daya cerna protein roti tawar disebabkan penambahan tepung tempe kedelai. Tepung tempe kedelai dibuat dari tempe kedelai dari bahan kedelai murni. Tempe kedelai sebagai bahan pangan sumber protein mudah dicerna (92$100 \%) .{ }^{33}$ Pengolahan kedelai menjadi tempe melalui fermentasi oleh kapang dapat menghidrolisis senyawasenyawa kompleks menjadi senyawa sederhana yang mudah dicerna oleh manusia. ${ }^{31}$

Pengolahan dapat menaikkan dan menurunkan nilai cerna protein.Protein dapat terdenaturasi dan daya cerna protein akan menurun oleh larutan asam dan pemanasan suhu tinggi seperti pada proses pengovenan pada roti tawar yang dilakukan pada suhu $190^{\circ} \mathrm{C} 60$ menit. Hal ini sangat relevan dengan penelitian sebelumnya (2009) tentang kualitas protein secara in vitro pada tempe kedelai hitam dengan berbagai variasi pengolahan menunjukkan bahwa daya cerna protein menurun seiring dengan suhu pengolahan. ${ }^{31}$

Pola perubahan antara kadar protein dan nilai daya cerna protein menunjukkan bahwa semakin meningkat kadar protein roti tawar semakin meningkat daya cerna proteinnya

Pola perubahan antara kadar protein dan daya cerna protein roti tawar telah memberi gambaran bahwa penambahan tepung tempe kedelai dapat meningkatkan mutu gizi protein roti tawar. Tepung tempe kedelai dibuat dari kedelai yang difermentasi oleh kapang Rhizopus. Fermentasi pada tempe kedelai menghidrolisis senyawa-senyawa kompleks menjadi senyawa sederhana yang mudah dicerna oleh manusia. Pada tempe, terdapat enzim-enzim pencernaan yang dihasilkan oleh kapang tempe selama proses 
fermentasi, sehingga protein, lemak, dan karbohidrat menjadi lebih mudah dicerna. Kapang yang tumbuh pada tempe mampu menghasilkan enzim protease untuk menguraikan protein menjadi peptide dan asam amino bebas. ${ }^{31}$

\section{SIMPULAN}

Substitusi tepung terigu dengan tepung ubi kayu yang dimodifikasi menggunakan metode fisik (perebusan) dan tepung tempe kedelai berpengaruh terhadap volume roti tawar ditoleransi pada formulasi 45:15 gram serta mutu gizi protein yang paling tinggi pada formulasi 90:30 gram.

\section{DAFTAR PUSTAKA}

1. Enny KB, Yulistiani R, Hidayat R. Kajian substitusi tepung tapioka dan penambahan gliserol monostearat pada pembuatan roti tawar (online). (2014 Oktober 14): 125-137.Available from: ejournal.upnjatim.ac.id.

2. Ashraf S, Anjum FM, Nadeem M, Riaz A. Functional and technological aspects of resistant starch. Food Science. 2012; 22(2): 90-95.

3. Arlene A, Witono JR, Fransisca M. Pembuatan roti tawar dari tepung singkong dan tepung kedelai. In Simposium Nasional RAPI VIII; Bandung; 2009. p. 80-84

4. Wulan SN, Suparianti E, Widjanarko SB, Kurnaeni N. Modifikasi pati sederhana dengan metode fisik, kimia, dan kombinasi fisik-kimia untuk menghasilkan tepung pra-masak tinggi pati resisten. Teknologi Pertanian. 2006; 07(01).1-9.

5. Aigster A. Physicochemical and sensory properties of resistant starch-based cereal products and effects on glycemic and oxidative stress responses in hispanic women (Dissertatation). Virginia: Virginia Polytechnic Institute, Human Nutrition, Foods and Exercise; 2009.

6. Hapsari TP, Zainul A, Matheus N. Pengaruh pre gelatinisasi terhadap karakterisitk tepung singkong. Teknologi Pertanian Universitas. 2007.7(1): 1-9.

7. Muchtadi D. Kedelai komponen untuk kesehatan. Bandung: Alfabeta; 2010.

8. Bastian F, Ishak E, Tawali AB, Bilang M. Daya terima dan kandungan zat gizi formula tepung tempe dengan penambahan semi Refined carrageenan (SRC) dan bubuk kakao. Aplikasi Teknologi Pangan. 2013; 2(1): 5-8

9. Utari DM, Rimbawan, Riyadi H, Muhilal, Purwantyastuti. Potensi asam amino pada tempe untuk memperbaiki profil lipid dan diabetes mellitus. Kesehatan Masyarakat Nasional. 2011; 5(4): 166-170.
10. Lean MEJ. Food science, nutrition and health. VII ed. Prasetyo dD, Setyaningrum, editors. Yogyakarta: Pustaka Pelajar; 2006.

11. Shittu TA, Raji AO, Sanni LO. Bread from composite cassava-wheat flour: I. effect of baking time and temperature on some physical properties of bread loaf. Elsevier. 2006;40: 280-290.

12. Faizah DN. Substitusi tepung tempe pada produk beragi (Karya Tulis). Yogyakarta: Uiversitas Negeri Yogyakarta; 2012.

13. Eddy NO, Udofia PG, Eyo D. Sensory evaluation of wheat/cassava composite bread and effect of label information on acceptance and bread. Biotechnology. 2007; 06(20): 1-4

14. Eriksson E. Flour From Three Local Varieties Of Cassava (Manihot Esculenta Crantz): Physicochemical properties, bread making quality and sensory evaluation (Thesis). Ghana: Faculty of Natural Resources and Agricultural sciences, Food Science; 2013.

15. Hardoko, Hendarto L, Siregar TM. Pemanfaatan ubi jalar ungu (Ipomoea Batatas L.Poir) sebagai pengganti sebaian tepung terigu dan antioksidan pada roti tawar. Teknologi dan Industri Pangan. 2010; 21(1): 25-32.

16. Nasional Dewan Standarisasi. Standar Nasional Indonesia (SNI) 01-3751-2009 :Tepung terigu untuk bahan makanan. Jakarta: BSN; 2009.

17. Juniardi W, Kusrini Novira, Suyatno A. Analisis distribusi pendapatan petani ubi kayu pola kemitraan dan bukan kemitraan pada PT. Sari Pati Semudun Jaya di Desa Bukit Bayu Kecamatan Sungai Kunyit Kabupaten Pontianak. Sains. 2012; 1(1):1-9.

18. Suprapti L. Tepung tapioka, pembuatan dan pemanfaatan. Yogyakarta: Karnisius; 2005.

19. Bastian F. Teknologi pati dan gula, hibah penulisan buku ajar bagi tenaga akademik Universitas Hasanudin. Makasar: UNHAS; 2011: p. 22-23

20. Herawati H. Teknologi proses produksi food ingredient dari tapioka termodifikasi. Litbang Pertanian. 2012; 31(2): 68-76.

21. Elemo GN. The prospects and challenges of cassava bread and confectionaries in Nigeria. The Niser Research Seminar Series; 2013 Mar 26; Ibadan FIRO.Nigeria: 2013. p. 1-56

22. Khan MI. Utilization of soybean as a functional food (Thesis). Faisalabad: University Of Agriculture, Food Science dan Technology; 2009.

23. Udofia, Uduodo, Eyen. Sensory evaluation of wheat-cassava-soybean composite flour (WCS) bread by mixture experiment design. Academic. 2013; 7(10): p.1- 7.

24. Eshun G. Baseline data on the nutrient content and phycicochemical properties of selected varieties 
of soybean, groundnut and rice for the development of nutritious, energy-dense diet. (Thesis). Ghana: University Of Science And Technology; 2009.

25. Nurhidajah, Anwar S, Nurrahman. Daya terima dan kualitas protein in vitro tempe kedelai hitam (Glycine soja) yang diolah pada suhu tinggi. Gizi Indonesia (online). 2009 Oct 9 (2014 Nov 25): p111. Available from: http://eprints.undip.ac.id/935/.

26. Omosebi OM, Otunela ET. Preliminary studies on tempeh flour produced from tree different rhizopus species. Biotechnology and Food Science. 2013; 1(15): 90-96.

27. Ginting P, Ginting S, Limbong NL. Pengaruh perbandingan tepung talas dengan tepung tempe dan konsemtrasi baking soda terhadap mutu krupuk talas. Rekayasa Pangan dan Peternakan. 2013;1: 29-38.

28. Widodo R, Harijanto SD, Rosidah DA. Aspek mutu produk roti tawar untuk diabetisi berbahan baku tepung porang dan tepung suweg. Agroknow. 2014; 2(1):1-12.

29. Setyaningsih D, Apriyantono A, Sari MP. Analisis sensori untuk Industri Pangan dan Argo. Sardin DS, editor. Bogor: IPB Press; 2010.

30. Jurusan Teknologi Pangan dan Gizi. Roti manis. Teknologi Pangan dan Agroindustri (online). 2014 Okt 23; 1(6): p. 82-86. Available from: http://www.warintek.ristek.go.id/pangan_kesehat an/pangan/ipb/Roti manis.pdf.

31. Faridah DN. Sifat fisiko-kimia tepung suwek (Amorphophallus Campnulatus B1.) dan indeks glikemiknya. Teknologi dan industri pangan. 2005; 16(3): 254-259.

32. Hoerudin. Indeks glikemik buah dan implikasinya dalam pengendalian kadar glukosa darah. Teknologi Pascapanen Pertanian. 2012;8(2): 8098.

33. Hasan V, Astuti S, Susilawati. Indeks glikemik oyek dan tiwul dari umbi garut (Marantha arundinaceae L.), suweg (Amorphallus campanullatus BI) dan singkong (Manihot utillisima). Teknologi Industri dan Hasil Pertanian. 2011; 18(1): 34-50.

34. Hasan V, Astuti S, Susilawati. Indeks glikemik oyek dan tiwul dari umbi garut (Marantha arundinaceae L.), suweg (Amorphallus campanullatus BI) dan singkong (Manihot utillisima). Teknologi Industri dan Hasil Pertanian. 2011; 18(1): 34-50.

35. Satjilata MG, Singhai, Rekha S, Kulkarni, Pushpa R. Resistant Starch. Comprehensive reviews in food science and food safety. 2006; 5: 1-17.
36. Riyanto A. Aplikasi metodologi penelitian kesehatan. Yogyakarta: Nuha Medika; 2011.

37. Naftali K, Ariputra B. 53 Resep roti untuk dijual. Jakarta: PT Media Boga Utama; 2013.

38. Tanujaya B. Penelitian percobaan. Kamsyach A, editor. Bandung: PT Remaja Rosdakarya; 2013. 